Sains Malaysiana 49(12)(2020): 2881-2890

http://dx.doi.org/10.17576/jsm-2020-4912-01

\title{
Adsorption Isotherm of Densed Monoclinic Tungsten Trioxide Nanoparticles
}

(Penjerapan Isoterma oleh Zarah Nano Monoklin Tungsten Trioksida Padat)

\author{
ASEP BAYU DANI NANDIYANTO*, RISTI RAGADHITA \& JUMRIL YUNAS
}

\section{ABSTRACT}

This study evaluated isotherm adsorption of densed monoclinic tungsten trioxide ( $\left.\mathrm{WO}_{3}\right)$ nanoparticles. To ensure the prepared particles were dense, experiments were conducted by combining ball-milling process and calcination of ammonium pentahydrate powder, in which all experiments were done with no additional chemicals or solvents. The adsorption process was carried out by adsorbing curcumin (as a model of adsorbate) in the batch process at ambient temperature and constant $\mathrm{pH}$ and the results was compared to several isotherm models: Langmuir, Freundlich, Temkin and Dubinin-Radushkevich models. To support the analysis, several characterizations were conducted: scanning electron microscope, X-ray diffraction and Fourier transform infrared. Experimental results showed that during the adsorption process, physical and chemical interactions occur simultaneously. The physical interactions happen when the adsorbate molecules attach directly to the surface of the adsorbent, forming monolayer adsorption. The chemical interaction is for the interaction between adsorbate molecules and occurs on above the formed main monolayer adsorption. The results were also completed with the proposal mechanism in the adsorption process. This study is important for supporting the fundamental researches in the photochemical reaction using $\mathrm{WO}_{3}$ catalyst.

Keywords: Adsorption isotherm; curcumin; education; monolayer interaction; tungsten trioxide

\section{ABSTRAK}

Kajian ini bertujuan untuk menilai penjerapan zarah nano tungsten trioksida ( $\left.\mathrm{WO}_{3}\right)$. Zarah nano $\mathrm{WO}_{3}$ disediakan oleh proses pengisar bebola dan pengkalsinan amonium pentahidrat, dengan semua proses dilakukan tanpa ada bahan kimia atau pelarut. Proses penjerapan dilakukan dengan menjerap kurkumin (sebagai model penyerap) dalam proses kelompok pada suhu ambien dan pH malar dan hasilnya dibandingkan dengan beberapa model isoterma: model Langmuir, Freundlich, Temkin dan Dubinin-Radushkevich. Untuk menyokong analisis, beberapa pengkhususan telah dijalankan: pengimbasan mikroskop elektron, sinar-x difraksi dan inframerah transformasi Fourier. Hasil uji kaji menunjukkan bahawa semasa proses penjerapan, interaksi fizikal dan kimia berlaku secara serentak. Interaksi fizikal berlaku apabila molekul adsorbat melekat terus ke permukaan penjerap, membentuk penjerapan ekalapis. Interaksi kimia adalah untuk interaksi antara molekul adsorbat pada bahagian atas penjerapan ekalapis utama. Untuk menyokong analisis, hasilnya dilengkapkan dengan mekanisme cadangan dalam proses penjerapan. Kajian ini adalah penting untuk menyokong penyelidikan asas dalam tindak balas fotokimia menggunakan pemangkin $\mathrm{WO}_{3}$.

Kata kunci: Interaksi ekalapis; isoterma penjerapan; kurkumin; pendidikan; tungsten trioksida

\section{INTRODUCTION}

Tungsten trioxide $\left(\mathrm{WO}_{3}\right)$ is one of the n-semiconductor materials that has been attracted researchers for decades due to its fascinating physical and chemical characteristics such as innocuous, mechanically strong, chemically and thermally stable, good optical properties, chemically inert, extensive band gap, inexpensive and environmentally friendly, as well as its ability in adsorbing visible light (Munawaroh et al. 2017; Navarrete et al. 2020; Santos et al. 2016). These advantages allow
$\mathrm{WO}_{3}$ material to be useful and suitable for wide range of applications, particularly for high-tech applications such as optoelectronics, microelectronics, selective catalysis, the textile industry, gas sensors, and environmental engineering (Nandiyanto et al. 2020a, 2016a, 2013).

Many reports have discussed $\mathrm{WO}_{3}$ nanoparticles from fabrication, characterization, to application in realistic uses. However, reports on understanding the adsorption process of adsorbate on $\mathrm{WO}_{3}$ material are very limited. In fact, this information is important for understanding how $\mathrm{WO}_{3}$ works, especially in the photo-related applications. 
To understand the adsorption process on the surface of $\mathrm{WO}_{3}$, isotherm adsorption is typically used. The isotherm adsorption explains the basic information for understanding and predicting what phenomena happening during the adsorption process (Ragadhita et al. 2019). These adsorption isotherm equations depend on the type of surface phase on the adsorbent, whether it can be considered for the formation of monolayer or multilayer. The calculations are also influenced by structural and energetic heterogeneous surface adsorbents (Adhikari et al. 2017; Zhao et al. 2016).

Several reports on the adsorption properties of $\mathrm{WO}_{3}$ have been published. Adhikari et al. (2017) studied the adsorption of dyes using $\mathrm{WO}_{3}$ nanoparticles as the adsorbents. Nonlinear regression analysis for isotherm models showed that Langmuir is well-fitted to the experimental data than the Freundlich and LangmuirFreundlich isotherm models. Zhao et al. (2016) investigated the dye adsorption using $\mathrm{WO}_{3}$ nanowires. Experimental data were analyzed using the Langmuir and Freundlich models and the results of the linear regression showed that the Langmuir model provided better fitting analysis than the Freundlich model. However, these reports did not predict what phenomena happen during the adsorption process, while this is important for further developments of $\mathrm{WO}_{3}$ material.

The purpose of this study was to evaluate isotherm adsorption of densed monoclinic tungsten trioxide $\left(\mathrm{WO}_{3}\right)$ nanoparticles. To ensure the prepared particles were dense, experiments were done by combining ball-milling process and calcination of ammonium pentahydrate (ATP) powder, in which all experiments were conducted with no additional chemicals or solvents. As a model of adsorbate, curcumin was used because it has ideal size for models of organic molecules (less than $1.4 \mathrm{~nm}$ ). The adsorption process was carried out by adsorbing curcumin in the batch process at ambient temperature and constant $\mathrm{pH}$ and the results were compared to several isotherm models: Langmuir, Freundlich, Temkin, and DubininRadushkevich.

\section{MATERIALS AND Methods}

Materials used were ATP ( $>99 \%$; Kanto Chemical Co., Inc., Japan) and curcumin solution. Curcumin was obtained by extraction process of turmeric (obtained from local market in Bandung, Indonesia), in which detailed information for the extraction process is reported in our previous studies (Nandiyanto et al. 2017, 2016b).

$\mathrm{WO}_{3}$ nanoparticles were produced by two steps: ball-milling ATP powder and followed by calcination process. All processes were done without additional chemicals and solvents. The ball-milling process was done for $8 \mathrm{~h}$ (detailed information for the ball-milling apparatus is explained in previous reports (Nandiyanto et al. 2018a, 2018b). The calcination process was done by putting the ball-milled ATP into the electrical furnace in the atmospheric conditions under a fixed condition: a heating rate of $50{ }^{\circ} \mathrm{C} \mathrm{min}{ }^{-1}$, holding at $500{ }^{\circ} \mathrm{C}$ for $30 \mathrm{~min}$ and cooling with a rate of $50{ }^{\circ} \mathrm{C} \mathrm{min}^{-1}$.

The prepared particles were analyzed using several characterizations: A scanning electron microscopy (SEM; JSM-6360LA; JEOL Ltd., Japan), Fourier transform infrared (FTIR; FTIR-4600, Jasco Corp., Japan), X-ray diffraction (XRD; PANalytical X'Pert PRO; Philips Corp., The Netherland).

In order to analyze the isotherm adsorption of $\mathrm{WO}_{3}$, $\mathrm{WO}_{3}$ particles were mixed with curcumin solution and put into the batch-type adsorption apparatus (a borosilicate glass reactor ( $400 \mathrm{~mL}$ capacity; dimensions of 10 and $8 \mathrm{~cm}$ for height and diameter, respectively); magnetic stirrer $(1500 \mathrm{rpm}))$. In the experimental procedure, $200 \mathrm{~mL}$ of curcumin solution were used with various concentrations from 20 to $100 \mathrm{ppm}$. During the adsorption process, the mixed solution was stirred. At a certain time, aliquot samples were taken for centrifugation (1100 rpm; $5 \mathrm{~min}$ ) and analyzed using a visible spectroscopy (Model 7205; JENWAY; Cole-Parmer; US; analyzed at maximum wavelengths in the range between 280 and $600 \mathrm{~nm}$ ).

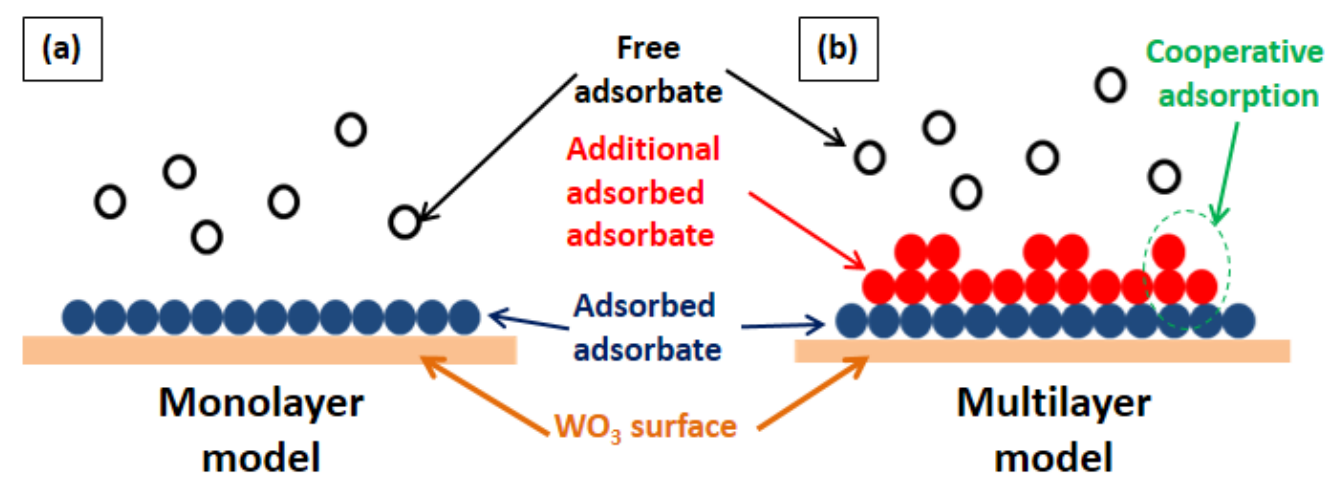

FIGURE 1. Adsorption model: (a) monolayer and (b) multilayer 
The spectroscopy analysis results were normalized, put into Beer-law model and compared with several isotherm models: Langmuir, Freundlich, Temkin, and Dubinin-Radushkevich adsorption models. Illustration models for the adsorption process is shown in Figure 1.

The Langmuir isotherm describes the monolayer adsorption process (Figure 1(a)). In short, the adsorbent has the ability to adsorb only one adsorbate molecule and no interaction between the adsorbate molecules happens. The Langmuir isotherm equation is described as (1):

$$
\frac{1}{q_{e}}=\frac{1}{Q_{\max } K_{L}} \frac{1}{C_{e}}+\frac{1}{Q_{\max }}
$$

where $C_{e}$ is the adsorbate equilibrium concentration (mg $\left.\mathrm{L}^{-1}\right) ; q_{e}$ is the amount of substance adsorbed per gram of adsorbent $\left(\mathrm{mg} \mathrm{g} \mathrm{g}^{-1}\right) ; K_{L}$ is the Langmuir adsorption constant; and $Q_{\max }$ is the capacity of the adsorbent monolayer $\left(\mathrm{mg} \mathrm{g}^{-1}\right)$. The equation is then used for understanding the separation factor as a dimensionless constant using (2):

$$
R_{L}=\frac{1}{1+K_{L} C_{e}}
$$

$R_{L}$ value is used to classify the adsorption process. The $R_{L}$ value is described as follows:

(i) If $R_{L}>1$, Unfavorable adsorption process (instead of adsorption, desorption process is quite happening).

(ii) If $R_{L}=1$, linear adsorption process (the adsorption isotherm depends on adsorbed amount and concentration). (iii) If $R_{L}=0$, Irreversible adsorption process (that adsorption is too strong).

(iv) If $0<R_{L}<1$, Favorable adsorption process (adsorption occurs normally and is controllable under specific condition).

The Freundlich isotherm model states that the adsorption process occurs on heterogeneous surfaces (Figure 1(b)). Each active group contained in the adsorbent has different adsorption abilities. Interactions between the adsorbate molecules are possible, forming a multilayer layer on the surface of adsorbent. The Freundlich isotherm equation is described as (3):

$$
\log q_{e}=\log k_{f}+\frac{1}{n} \log C_{e}
$$

$Q_{e}$ is the amount of adsorbate absorbed per unit of adsorbent $\left(\mathrm{mg} \mathrm{g}^{-1}\right) ; k_{f}$ is the Freundlich constant; $C_{e}$ is the concentration of adsorbate under equilibrium conditions ( $\mathrm{mg} \mathrm{L}^{-1}$ ); and $n$ is the value indicating the degree of linearity between the adsorbate solution and the adsorption process. The value of $n$ is described as follows: (i) if $n=1$, linear adsorption process (the adsorption isotherm depends on adsorbed amount and concentration); (ii) if $n<1$, chemical adsorption process;

(iii) if $n>1$, physical adsorption process.

(iv) if $0<1 / n<1$, favorability of adsorption process (adsorption occurs normally and is controllable under specific condition)

(v) if $1 / n>1$, cooperative adsorption (Figure 1(b); adsorbed adsorbate has an effect on the adsorption of 'new' adsorbate molecules).

The Temkin isotherm model states that the reduction in heat of adsorption from all molecules in the surface layer is linear and the adsorption is a characterization of the uniformity of the binding energy distribution. The Temkin adsorption equation model is described as in (4):

$$
q_{e}=\beta_{T} \ln A_{T}+\beta_{T} \ln C_{e}
$$

where $A_{T}$ is the binding equilibrium constant; $b_{T}$ is the adsorption heat constant; $T$ is absolute temperature. If $b_{T}$ is smaller than $8 \mathrm{~kJ} \mathrm{~mol}^{-1}$, that is actually an adsorption process physically.

The Dubinin-Radushkevich isotherm model expressed the mechanism of adsorption with the distribution of Gaussian energy in heterogeneous surfaces, which is described as (5):

$$
\ln q_{e}=\ln q_{s}-\left(\beta \varepsilon^{2}\right)
$$

where $q_{s}$ is the saturation capacity of theoretical isotherms; $\beta$ is the Dubinin-Radushkevich isotherm constant and $\varepsilon$ is the Polanyi potential $\left(\mathrm{J} \mathrm{mol}^{-1}\right)$. Then, (4) relates to (6) and (7).

$$
\begin{gathered}
\varepsilon=R T \ln \left(1+\frac{1}{C_{e}}\right) \\
E=\frac{1}{\sqrt{2 \beta}}
\end{gathered}
$$

where $E$ is the adsorbate energy per molecule as the energy needed to remove molecules from the surface. The following results can be obtained:

if $E<8 \mathrm{~kJ} \mathrm{~mol}^{-1}$, physical adsorption; if $8<E<168 \mathrm{~kJ} \mathrm{~mol}^{-1}$, chemical adsorption.

\section{RESULTS AND DISCUSSION}

Figure 2(a) and 2(b) depicts the SEM images of ATP before and after ball-milling process followed by calcination, respectively. Initial ATP powder has particle sizes of about $30 \mu \mathrm{m}$ with polyhedral forms (Figure 2(a)), whereas the ball-milled and calcined ATP particles were spherical with sizes of about $30-100 \mathrm{~nm}$ (Figure 2(b)). The main reason for the successful size-reduction of material is due to the additional ball-milling process (Nandiyanto 
et al. 2018a, 2018b). The ball-milling method is effective for reducing the size of materials, which is feasible for mechanochemical approach in laboratory and industrial scale (Jiang et al. 2019; Li et al. 2016). In Figure 2(b), the appearance of particles seemed to be agglomerated, in which this is due to the sputtering process.

The FTIR analysis is presented in Figure 2(c). Initial ATP powder has peaks in the wavenumber area of 1600 and $3600 \mathrm{~cm}^{-1}$ (corresponding to $\mathrm{OH}$ - structure), 1400 and $3200 \mathrm{~cm}^{-1}$ (corresponding to N-H bonding) and below 1000 $\mathrm{cm}^{-1}$ (corresponding to specific peaks for tungsten). $\mathrm{WO}_{3}$ nanoparticles (after calcination at $500{ }^{\circ} \mathrm{C}$ ) have different peaks without wavenumber for $\mathrm{OH}-$ and the $\mathrm{N}-\mathrm{H}$ bonding, indicating the removal of water and ammonium molecules from ATP (Fait et al. 2016; Nandiyanto et al. 2017).

Figure 2(d) shows the XRD analysis of ATP before and after ball-milling followed by calcination process. The XRD results confirmed that the initial ATP is pure and $\mathrm{WO}_{3}$ nanoparticles corresponded to monoclinic $\mathrm{WO}_{3}$ pattern (based on Joint Committee Powder Diffraction System (JCPDS) No. 72-1465) (Nandiyanto et al. 2020b). $\mathrm{WO}_{3}$ sample has the predominant peaks at $2 \theta$ of 23.04,
$23.75,24.11,28.78,33.00,34.00,35.00,41.80,47.20$, 49.70 and $62.00^{\circ}$, corresponding to $(100),(020),(200)$, (112), (022), (202), (103), (222), (040), (440) and (620) planes of $\mathrm{WO}_{3}$, respectively (Kumar et al. 2018; Liu et al. 2015).

Figure 3 shows the effect of adsorbent amount (i.e. $0.05,0.10$, and $0.15 \mathrm{~g}$ on $50 \mathrm{ppm}$ of curcumin solution) on adsorption efficiency of $\mathrm{WO}_{3}$ nanoparticles. The results replied that increases in the dosages have a correlation to the increases in the adsorption ability, which are due to the increases number of active sites. However, further increases in the dosages have no impact on the improvement of adsorption ability. Too much particles added have consequences to the possibility in the agglomeration between adsorbent (Kumar et al. 2010; Piccin et al. 2011). In this analysis, three data were presented, in which this is an ample measurement to predict analysis of the effect of mass dosage on the adsorption process. Indeed, too less $\mathrm{WO}_{3}$ amount will bring less adsorption efficiency, whereas too high dosage of $\mathrm{WO}_{3}$ do not provide better adsorption process. Too high amount of $\mathrm{WO}_{3}$ also gives misleading measurements since it can create high turbidity level (spectrometer cannot measure
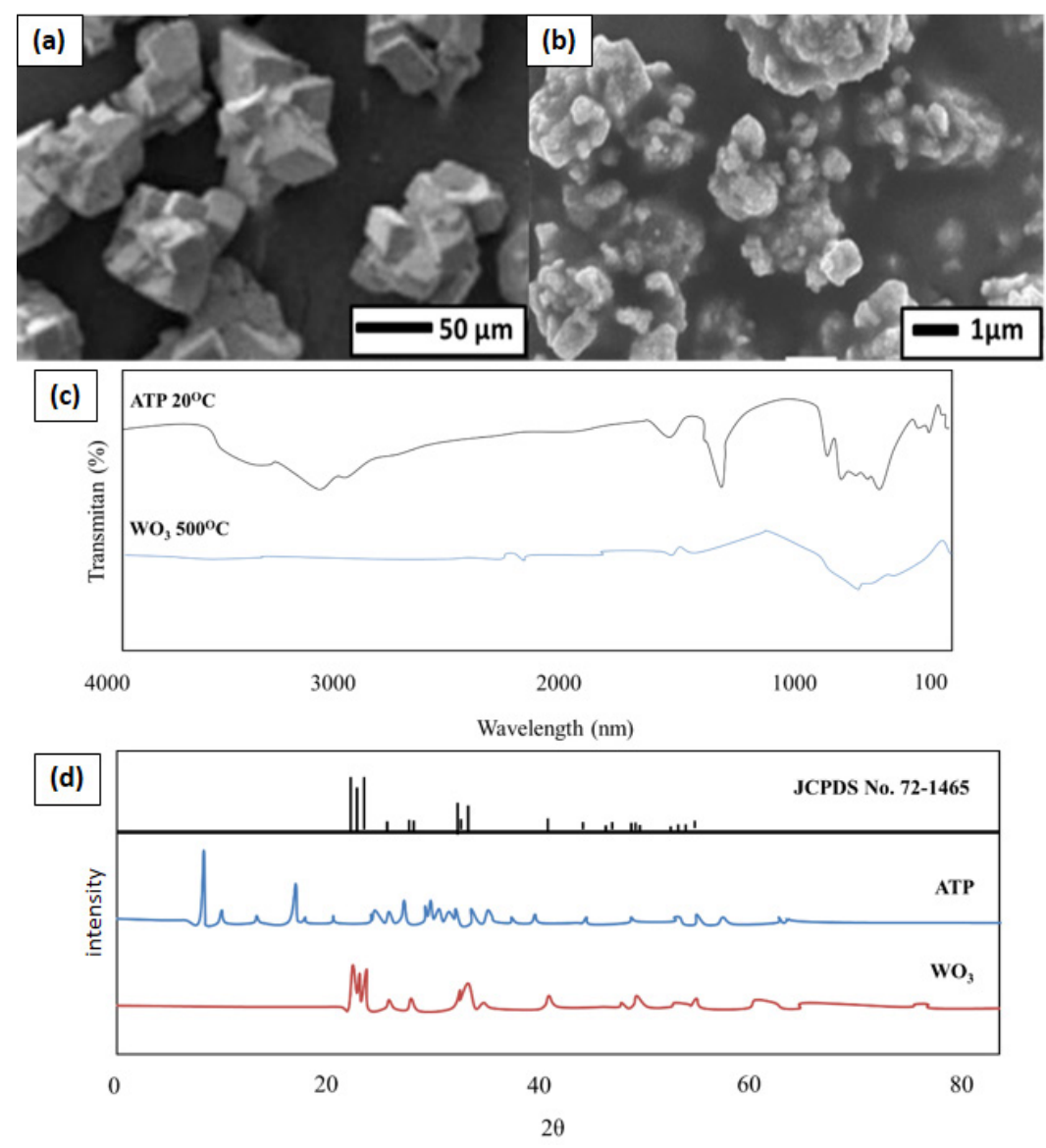

FIGURE 2. The SEM (a, b), the FTIR (c), the XRD (d) analysis results of samples. (a) and (b) are samples of ATP before and after the heat treatment, respectively. 
precisely). However, additional data is required for getting precise analysis, in which this will be done in our future work. Based on the results, the optimum mass of $\mathrm{WO}_{3}$ nanoparticles for the adsorption process is $0.10 \mathrm{~g}$, which was then used for further analysis.

Figure 4 shows the effect of adsorption time on the adsorption efficiency. The study varied the adsorption time from 0 to $75 \mathrm{~min}$, which is an enough time to analyze the optimum adsorption time. The process was done without illumination to ensure no photochemical reaction during the adsorption process $\left(\mathrm{WO}_{3}\right.$ is active in absorbing visible light (Nandiyanto et al. 2020a, 2020b)). Thus, all decoloration of curcumin is purely from adsorption process. It is clearly found that increases in the adsorption time give a positive impact for adsorption ability. The adsorbent can absorb the adsorbate solution up to 7.20 $\mathrm{mg} \mathrm{g}^{-1}$ for $45 \mathrm{~min}$ with an initial concentration of 50 ppm adsorbate solution and adsorbent doses of $0.10 \mathrm{~g}$. However, too long adsorption process can give negative impacts from deterioration of adsorption ability. Adsorbate seems to be released from the adsorbent, informing that the adsorbent was not strong enough to maintain the attached adsorbate. This is possibly due to two reasons: adsorbent is dense, making the adsorption process on the outer surface of adsorbent; and interaction between adsorbate and adsorbent occurs physically, which is easily destroyed by mechanical impact such as stirring process. Therefore, the optimum time is $45 \mathrm{~min}$, in which this will be used for further analysis (Ragadhita et al. 2019).

The effect of the initial concentration of the adsorbate solution on the adsorption efficiency is presented in Figure 5. The results showed that the optimum adsorption process at the initial adsorbate concentration of $50 \mathrm{ppm}$. Adsorption of the adsorbate molecules tends to increase with the increasing concentration of the solution. At the beginning of the adsorption process, the surface of the adsorbent is not too much bound with adsorbates, whereas at the optimum concentration of $50 \mathrm{ppm}$, the active site in the adsorbent has reached saturation due to all surfaces of the active site have been filled with adsorbates (Ragadhita et al. 2019).

Adsorption capacity increases with increasing initial concentration, which is caused by the availability of more adsorbate molecules in the solution to be adsorbed. This condition must be supported by the number of active area on the surface of $\mathrm{WO}_{3}$ adsorbent. However, when the concentration of adsorbate is too much, less efficiency of the adsorption process can be obtained. This is shown by the results in the optimum concentration of adsorbate that reach $50 \mathrm{ppm}$ and higher concentration of adsorbate will not bring good impacts to the adsorption process.

The more additional adsorbate amount can give more free adsorbates in the solution, while these free adsorbates bring negative influences:

(i) Disturbing the adsorption process (giving resistance in the adsorbate molecular diffusion and mass transfer from solution to the surface of solid adsorbent) (El-Araby et al. 2017; Pandey et al. 2010).

(ii) Disturbing the interaction between adsorbed adsorbates and surface of adsorbent (making desorption process occurring). This phenomenon must be confirmed by the analysis of the several isotherm adsorptions.

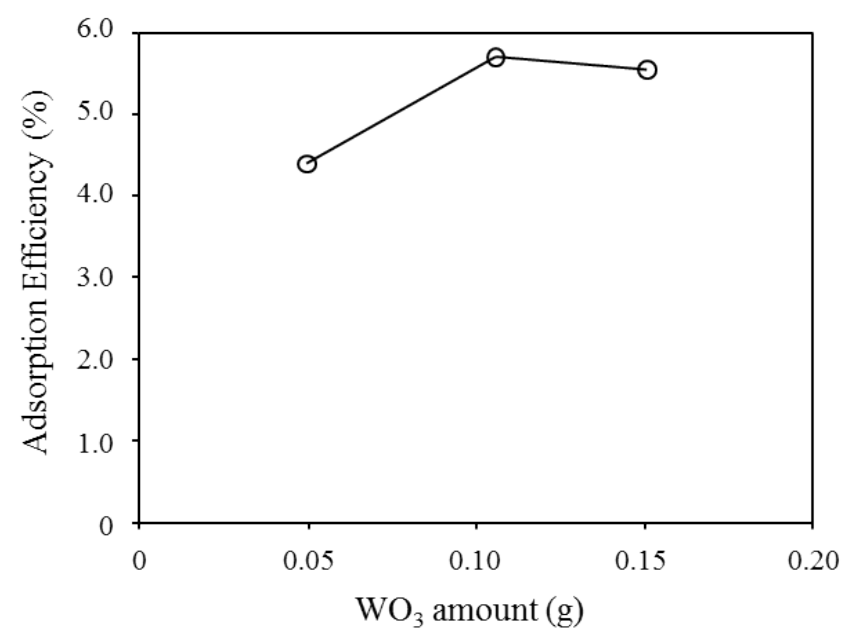

FIGURE 3. Effect of adsorbent amount on adsorption efficiency 


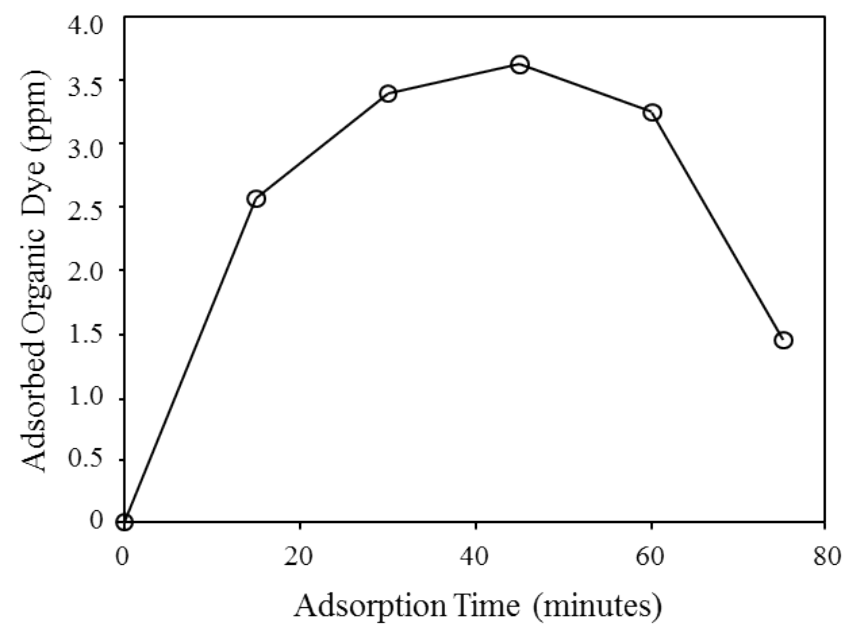

FIGURE 4. Effect of adsorption time on adsorbed organic dye

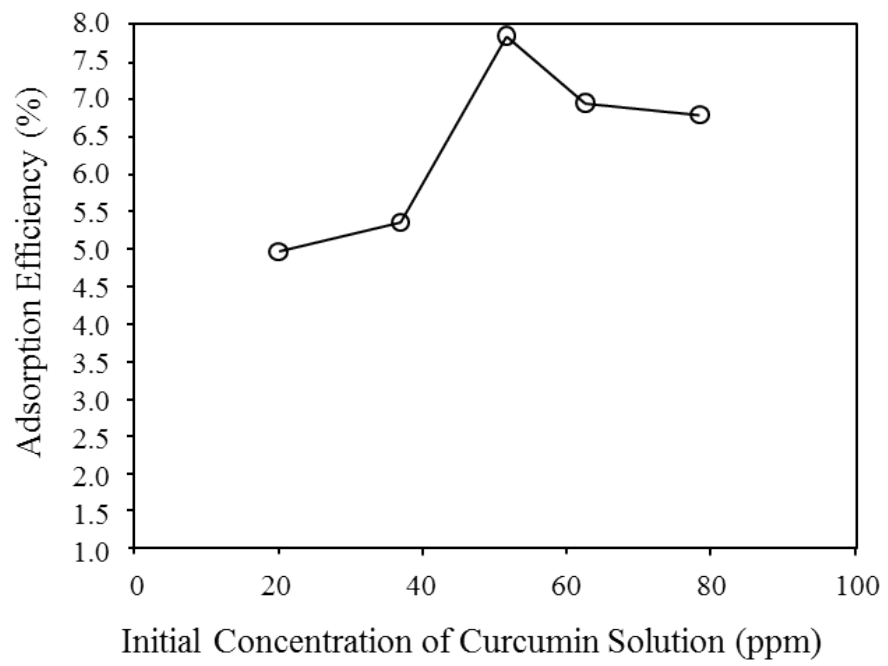

FIGURE 5. Effect of initial concentration of curcumin solution on adsorption efficiency

Analysis of the isotherm adsorption isotherms of $\mathrm{WO}_{3}$ nanoparticles are shown in Figure 6(a), 6(b), 6(c), and 6(d), corresponding to Langmuir, Freundlich, Temkin, and Dubinin-Radushkevich models. All data were then analyzed, normalized, and linearized based on (1)-(7). Direct analysis for the linearization is almost the same. Thus, the results are then concluded in Table 1 to show the best correlation coefficients. Based on the $\mathrm{R}^{2}$ fitting analysis, the best models were based on the following order: Langmuir $>$ Freundlich $>$ Temkin $>$ DubininRadushkevich models.
The Langmuir isotherm theory (using (1) and (2)) assumes monolayer coverage of the adsorbate over a homogenous adsorbent surface. From the Langmuir parameter values (presented in Table 1), the adsorbent has a maximum adsorption capacity $\left(Q_{\max }\right)$ of $13.420 \mathrm{mg}$ $\mathrm{g}^{-1}$ and the separation factor as a dimensionless constant $\left(R_{L}\right)$ assumed unfavorable adsorption process.

Adsorption equilibrium data was also analyzed based on the Freundlich isotherm model (using (3)). As shown in Table 1, the correlation coefficient value of the Freundlich model is indeed smaller than the correlation 

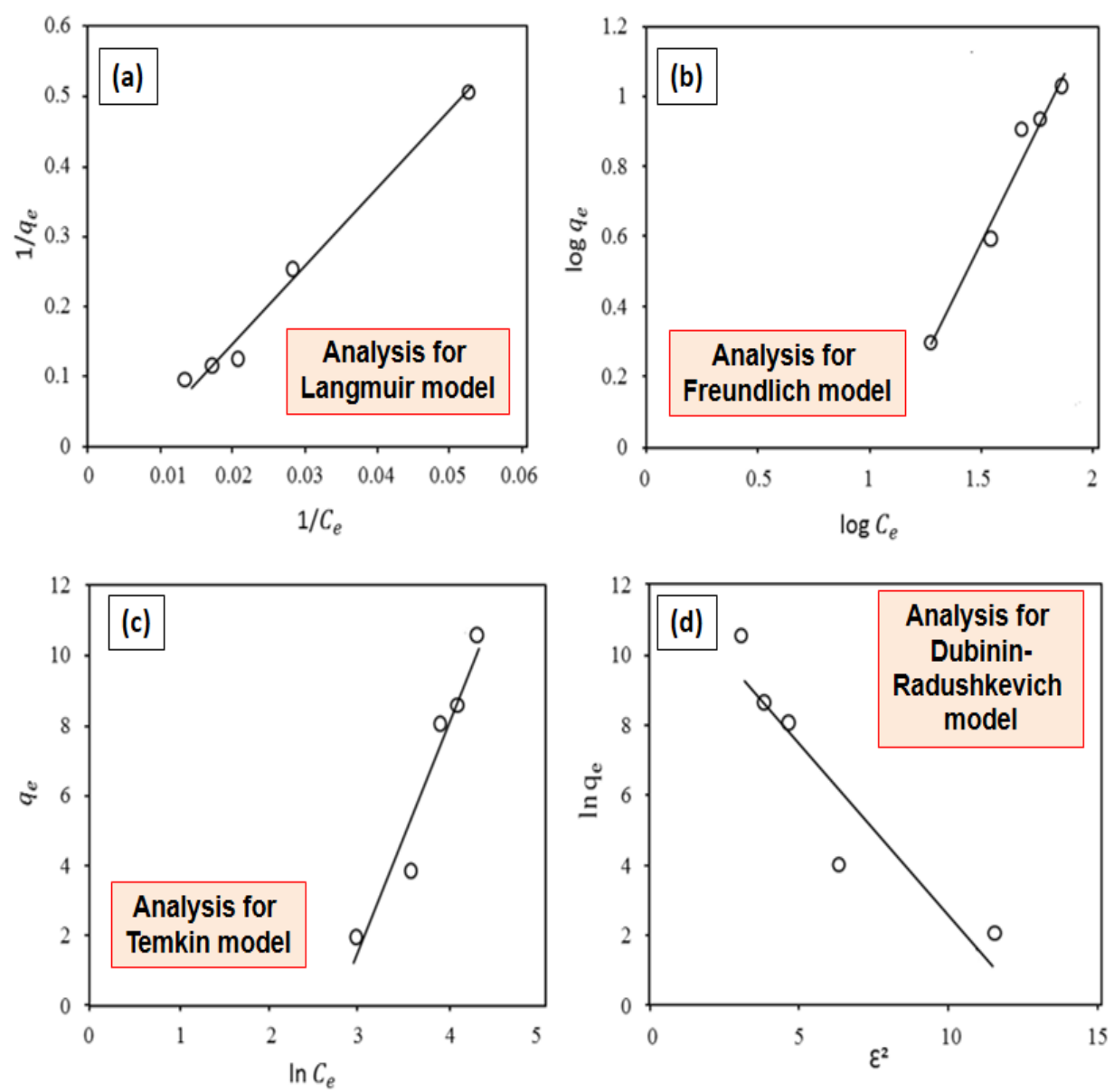

FIGURE 6. Adsorption analysis based on several models: (a) Langmuir,

(b) Freundlich, (c) Temkin, and (d) Dubinin-Radushkevich

coefficient value of the Langmuir model. The Freundlich parameter shows $1 / n>1$, confirming that the adsorption process is a cooperative model. We also found $n<1$, indicating the physical adsorption process.

Adsorption data were also analyzed based on the Temkin ((4)) and Dubinin-Radushkevich ((5)-(7)) models. The results showed that the adsorption process fits and matches with the Temkin model (using (4)) even though the correlation coefficient value is smaller than that in the Langmuir and Freundlich models (Table 1). The Temkin isotherm analysis confirmed that the adsorption process is physical adsorption because it has a $\beta_{T}$ value smaller than $8 \mathrm{~kJ} / \mathrm{mol}$.

The poorest experimental data was obtained for Dubinin-Radushkevich isotherm model ((5)-(7)), which is the lowest correlation coefficient among the four isotherm models in Table 1. However, based on fitting data to the Dubinin-Radushkevich model, the saturation capacity of the adsorbent is $12.33 \mathrm{mg} \mathrm{g}^{-1}$ and energy calculations confirmed that the adsorption process is physical adsorption.

All data confirmed that the type of adsorption is monolayer (Figure 1(a), in which this is in a good agreement with our hypothesis for the formation of dense $\mathrm{WO}_{3}$ nanoparticles) since the highest amount of $R^{2}$ relates to Langmuir model. The adsorbates attach on the surface of adsorbent physically, confirmed by the analysis from Temkin and Dubinin-Radushkevich isotherm models.

Illustration of the adsorption process on the surface of $\mathrm{WO}_{3}$ is depicted in Figure 7. The Langmuir analysis replied that the interaction between adsorbent surface and adsorbate occurs by the formation of monolayer. Their interactions happen physically, which were confirmed by Temkin and Dubinin-Radushkevich. The interaction phenomena are also verified by the value of $R_{L}$ in the Langmuir analysis, informing that instead of adsorption, 
desorption process is quite happening. The Freundlich analysis implied the existence of cooperative adsorption as well as chemical adsorption.

Based on these results, during the adsorption process, physical and chemical interactions occur simultaneously. The physical interactions happen when the adsorbate molecules attach directly to the surface of the adsorbent, forming monolayer adsorption. The chemical interaction is for the interaction between adsorbate molecules on the above main monolayer adsorption.

These hypothesis explained the main reason for the existence of optimum concentration of adsorbate in
Figure 5 (that excess concentration of adsorbate will not give better adsorption efficiency). The interaction between adsorbent surface and adsorbate is not strong enough and easily destroyed since it is a physical adsorption. This weak interaction is confirmed by the value of $R_{L}$ in the Langmuir analysis, showing the possible unfavorable adsorption (desorption process is quite happening). The possible destructive phenomenon on the formed adsorption monolayer happens and is supported by the Freundlich analysis that shows the existence of cooperative adsorption and chemical interaction among adsorbates.

TABLE 1. Model parameters of Langmuir, Freundlich, Temkin, and Dubinin Adsorption Isotherms - Radushkevich

\begin{tabular}{|c|c|c|c|}
\hline Model & Parameter & Value & Note \\
\hline \multirow[t]{5}{*}{ Langmuir } & $K_{L}\left(\mathrm{~L} \mathrm{mg}^{-1}\right)$ & 0.0068 & $\begin{array}{l}\text { Relatively small } K_{L} \text { values, indicating that there is a weak interaction } \\
\text { between adsorbate and adsorbent }\end{array}$ \\
\hline & $Q_{\max }\left(\mathrm{mg} \mathrm{g}^{-1}\right)$ & 13.420 & Representing the maximum adsorption capacity \\
\hline & $R_{L}$ & 1.5380 & $\mathrm{R}_{\mathrm{L}}>1$, Unfavorable Adsorption \\
\hline & $R^{2}$ & 0.9871 & The correlation coefficients \\
\hline & $k_{f}\left(\mathrm{mg} \mathrm{g}^{-1}\right)$ & 0.0414 & The adsorption capacity of the adsorbent \\
\hline \multirow[t]{4}{*}{ Freundlich } & $1 / n$ & 1.3118 & $1 / n$, Cooperative Adsorption \\
\hline & $n$ & 0.7623 & $n<1$, Chemical Adsorption \\
\hline & $R^{2}$ & 0.9699 & The correlation coefficients \\
\hline & $\beta_{T}\left(\mathrm{~kJ} \mathrm{~mol}^{-1}\right)$ & 0.3758 & $\beta_{T}<8 \mathrm{~kJ} \mathrm{~mol}^{-1}$, Physical Adsorption \\
\hline \multirow[t]{2}{*}{ Temkin } & $R^{2}$ & 0.9412 & The correlation coefficients \\
\hline & $Q_{s}\left(\mathrm{mg} \mathrm{g}^{-1}\right)$ & 12.330 & Theoretical isotherm saturation capacity \\
\hline Dubinin- & $E\left(\mathrm{~kJ} \mathrm{~mol}^{-1}\right)$ & 0.3820 & $E<8 \mathrm{~kJ} \mathrm{~mol}^{-1}$, Physical Adsorption \\
\hline Radushkevich & $R^{2}$ & 0.8556 & The correlation coefficients \\
\hline
\end{tabular}

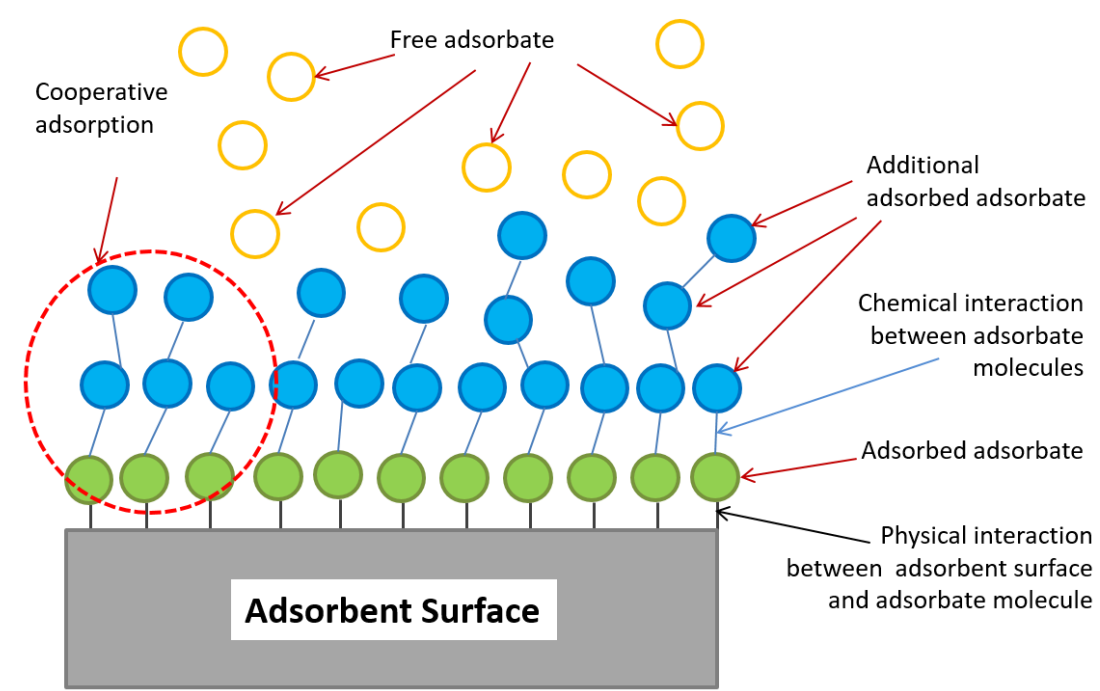

FIGURE 7. Proposal illustration of the adsorption process between $\mathrm{WO}_{3}$ (as the adsorbent) and curcumin (as the adsorbate) 


\section{CONCLUSION}

The present study evaluates the adsorption isotherm of $\mathrm{WO}_{3}$ nanoparticles. The evaluation was supported with varied initial amount of adsorbent, adsorption time and initial concentration of curcumin solution. Based on the results of plotting data on the Langmuir, Freundlich, Temkin, and Dubinin-Radushkevich adsorption models, the equilibrium data were best represented by the Langmuir isotherm model. The results showed that during the adsorption process, physical, and chemical interactions occur simultaneously. The physical interactions happen when the adsorbate molecules attach directly to the surface of the adsorbent, forming monolayer adsorption. The chemical interaction is for the interaction between adsorbate molecules on the above main monolayer adsorption. This study is important for supporting the fundamental researches in the photochemical reaction using $\mathrm{WO}_{3}$ catalyst.

\section{ACKNOWLEDGEMENTS}

This study acknowledged RISTEK DIKTI for Grant-in-aid Penelitian Terapan Unggulan Perguruan Tinggi (PTUPT).

\section{REFERENCES}

Adhikari, S., Mandal, S., Sarkar, D., Kim, D.H. \& Madras, G. 2017. Kinetics and mechanism of dye adsorption on $\mathrm{WO}_{3}$ nanoparticles. Applied Surface Science 420: 472-482.

El-Araby, H.A., Ibrahim, A.M.M.A., Mangood, A.H. \& Adel, A.H. 2017. Sesame husk as adsorbent for copper (II) ions removal from aqueous solution. Journal of Geoscience and Environment Protection 5(7): 109-152.

Fait, M.J., Moukhina, E., Feist, M. \& Lunk, H.J. 2016. Thermal decomposition of ammonium paratungstate tetrahydrate: New insights by a combined thermal and kinetic analysis. Thermochimica Acta 637: 38-50.

Jiang, A., Wang, F., Xia, D., Li, M., Qiang, L., Zhu, Z., Wang, P., Fan, R., Lin, K. \& Yang, Y. 2019. Aluminum nanoparticles manufactured using a ball-milling method with ammonium chloride as a grinding aid: Achieving energy release at low temperature. New Journal of Chemistry 43(4): 1851-1856.

Kumar, K.A., Chandana, L., Ghosal, P. \& Subrahmanyam, C.H. 2018. Simultaneous photocatalytic degradation of p-cresol and $\mathrm{Cr}(\mathrm{VI})$ by metal oxides supported reduced graphene oxide. Molecular Catalysis 451: 87-95.

Kumar, P.S., Vincent, C., Kirthika, K. \& Kumar, K.S. 2010. Kinetics and equilibrium studies of $\mathrm{Pb}^{2+}$ in removal from aqueous solutions by use of nano-silversol-coated activated carbon. Brazilian Journal of Chemical Engineering 27(2): 339-346.

Li, H., Wang, X., Liu, C., Ren, J., Zhao, X., Sun, R. \& Wu, A. 2016. An efficient pretreatment for the selectively hydrothermal conversion of corncob into furfural: The combined mixed ball milling and ultrasonic pretreatments. Industrial Crops and Products 94: 721-728.

Liu, F., Chen, X., Xia, Q., Tian, L. \& Chen, X. 2015. Ultrathin tungsten oxide nanowires: Oleylamine assisted nonhydrolytic growth, oxygen vacancies and good photocatalytic properties. RSC Advances 5(94): 77423 77428.

Munawaroh, H.S.H., Nandiyanto, A.B.D., Gumilar, G.G., Widi, A. \& Subangkit, M. 2017. Effect of oral administration of tungsten trioxide $\left(\mathrm{WO}_{3}\right)$ particles on hispathological feature of liver and kidney in rat. IOP Conference Series: Materials Science and Engineering 180(1): 012097.

Nandiyanto, A.B.D., Oktiani, R., Ragadhita, R., Sukmafitri, A. \& Zaen, R. 2020a. Amorphous content on the photocatalytic performance of micrometer-sized tungsten trioxide particles. Arabian Journal of Chemistry 13(1): 2912-2924.

Nandiyanto, A.B.D., Zaen, R. \& Oktiani, R. 2020b. Correlation between crystallite size and photocatalytic performance of micrometer-sized monoclinic $\mathrm{WO}_{3}$ particles. Arabian Journal of Chemistry 13(1): 1283-1296.

Nandiyanto, A.B.D., Andika, R., Aziz, M. \& Riza, L.S. 2018a. Working volume and milling time on the product size/ morphology, product yield, and electricity consumption in the ball-milling process of organic material. Indonesian Journal of Science and Technology 3(2): 82-94.

Nandiyanto, A.B.D., Zaen, R. \& Oktiani, R. 2018b. Working volume in high-energy ball-milling process on breakage characteristics and adsorption performance of rice straw ash. Arabian Journal for Science and Engineering 43(11): 6057-6066.

Nandiyanto, A.B.D., Wiryani, A.S., Rusli, A., Purnamasari, A., Abdullah, A.G., Widiaty, I. \& Hurriyati, R. 2017. Extraction of curcumin pigment from Indonesian local turmeric with its infrared spectra and thermal decomposition properties. IOP Conference Series: Materials Science and Engineering 180(1): 012136.

Nandiyanto, A.B.D., Munawaroh, H.S.H., Kurniawan, T. \& Mudzakir, A. 2016a. Influences of temperature on the conversion of ammonium tungstate pentahydrate to tungsten oxide particles with controllable sizes, crystallinities, and physical properties. Indonesian Journal of Chemistry 16(2): 124-129.

Nandiyanto, A.B.D., Sofiani, D., Permatasari, N., Sucahya, T.N., Wiryani, A.S., Purnamasari, A. \& Prima, E.C. 2016b. Photodecomposition profile of organic material during the partial solar eclipse of 9 March 2016 and its correlation with organic material concentration and photocatalyst amount. Indonesian Journal of Science and Technology 1(2): 132155.

Nandiyanto, A.B.D., Arutanti, O., Ogi, T., Iskandar, F., Kim, T.O. \& Okuyama, K. 2013. Synthesis of spherical macroporous $\mathrm{WO}_{3}$ particles and their high photocatalytic performance. Chemical Engineering Science 101: 523-532.

Navarrete, E., Bittencourt, C., Umek, P., Cossement, D., Güell, F. \& Llobet, E. 2020. Tungsten trioxide nanowires decorated with iridium oxide nanoparticles as gas sensing material. Journal of Alloys and Compounds 812: 152156.

Pandey, P.K., Sharma, S.K. \& Sambi, S.S. 2010. Kinetics and equilibrium study of chromium adsorption on zeolite NaX. International Journal of Environmental Science \& Technology 7(2): 395-404.

Piccin, J.S., Dotto, G.L. \& Pinto, L.A.A. 2011. Adsorption isotherms and thermochemical data of FD\&C Red $n$ 
40 binding by chitosan. Brazilian Journal of Chemical Engineering 28(2): 295-304.

Ragadhita, R., Nandiyanto, A.B.D., Nugraha, W.C. \& Mudzakir, A. 2019. Adsorption isotherm of mesopore-free submicron silica particles from rice husk. Journal of Engineering Science and Technology 14(4): 2052-2062.

Santos, L., Silveira, C.M., Elangovan, E., Neto, J.P., Nunes, D., Pereira, L. \& Almeida, M.G. 2016. Synthesis of WO nanoparticles for biosensing applications. Sensors and Actuators B: Chemical 223: 186-194.

Zhao, Z., Ping, N., Di, J. \& Zheng, H. 2016. Highly selective adsorption of organic dyes onto tungsten trioxide nanowires. Research on Chemical Intermediates 42(6): 5639-5651.

Asep Bayu Dani Nandiyanto* \& Risti Ragadhita

Departemen Kimia

Universitas Pendidikan Indonesia

Bandung

Indonesia
Jumril Yunas

Institute of Microengineering and Nanoelectronics (IMEN)

Universiti Kebangsaan Malaysia

43600 UKM Bangi, Selangor Darul Ehsan

Malaysia

*Corresponding author; email: nandiyanto@upi.edu

Received: 10 April 2020

Accepted: 29 April 2020 